University of Rhode Island

DigitalCommons@URI

Open Access Master's Theses

1995

\title{
For the Sake of Truth: A Discussion of Heidegger's Thought on Art
}

Mia Ruscetta

University of Rhode Island

Follow this and additional works at: https://digitalcommons.uri.edu/theses

\section{Recommended Citation}

Ruscetta, Mia, "For the Sake of Truth: A Discussion of Heidegger's Thought on Art" (1995). Open Access Master's Theses. Paper 1542.

https://digitalcommons.uri.edu/theses/1542

This Thesis is brought to you for free and open access by DigitalCommons@URI. It has been accepted for inclusion in Open Access Master's Theses by an authorized administrator of DigitalCommons@URI. For more information, please contact digitalcommons-group@uri.edu. 
4279

+149

rot?

1935

FOR THE SAKE OF TRUTH:

A DISCUSSION OF HEIDEGGER'S THOUGHT ON ART

BY

MIA RUSCETTA

A THESIS SUBMITTED IN PARTIAL FULFILLMENT OF THE REQUIREMENTS FOR THE DEGREE OF

MASTER OF ARTS

IN

PHILOSOPHY

UNIVERSITY OF RHODE ISLAND

1995

$338: 6 \div 4$ 


\section{ABSTRACT}

Heidegger's essay "The Origin of the Work of Art" contains difficult and often ambiguous concepts. This thesis attempts to clarify Heidegger's thoughts on works of art. The discussion begins with an examination of what Heidegger means by truth. The determination is that a thing's meaning in relation to our existence and what that meaning reveals about us constitutes Heideggerian truth. The disclosure of truth requires an encounter which allows things to direct us as to what they are. The possibility of our being directed is dependent upon the establishing of certain conditions. Equipment, science, technology, and language are investigated to determine whether or not they are able to establish the conditions which are necessary for the disclosure of truth. The conclusion is that they are not because they fall victim to our directives when we encounter them. Works of art are those things which are able to establish the necessary conditions for a proper encounter with things. Since things other than works of art are subject to our directives, artworks have become the only things which are able to disclose truth. This claim finds support through analysis of Heidegger's works "The Origin of the Work of Art", "The Essence of Truth", and "The Question Concerning Technology" and through a critical examination of commentaries on those works. 


\section{ACKNOWLEDGMENT}

I wish to thank Professors Ira Kuhn and Richard Bailey for their supportive participation in this endeavor.

I am particularly indebted to Professors Galen Johnson and Cheryl Foster for their patience, support, and guidance. Their efforts have empowered me to create the work which has emerged. My most heartfelt thanks to them.

Finally, a note of affection to those family and friends who had to endure my Heidegger days and to Professors Billy Joe Lucas and Raymond Langley who ignited my passion for Philosophy.

Remembering you too my pink rose!

- $x o$ 


\section{PREFACE}

This text attempts to prove that Heidegger understands works of art as being the only things which are able to disclose truth. Since Heidegger's essay "The Origin of the Work of Art" is often ambiguous, his essays "On the Essence of Truth" and "The Question Concerning Technology" are explored to help clarify his thought on works of art.

I attempt to explain Heideggerian truth in terms of existence, living. The discussion of truth then moves to an explanation of how it is attainable during our encounters with things. Heidegger's understanding of truth is not grounded in the leading interpretations of truth which determine truth through observation, sensation, or utility. Since Heideggerian truth requires that we be directed by the object, it becomes necessary to establish the conditions under which such an encounter becomes possible.

Before claiming that works of art are the only things which provide for a proper encounter with things, an encounter in which we are directed by the thing, it was necessary to explain why things other than works of art do not provide a proper encounter.

Equipment, science, technology, and language are evaluated in terms of the conditions necessary for the disclosure of truth. The result of the examination is that each falls victim to our directives of will during our common encounters with them.

Works of art, however, remove us from our common encounter with things. Thus removed, we are free to be directed by things. Works of art thereby become the only things which disclose truth. 
The discussion of the artwork includes an explanation of how works are able to achieve the conditions necessary for the disclosure of truth. Throughout my discussion, I have attempted to dissolve some of the ambiguity of Heidegger's thought. I hope that I have been successful in my attempts. 


\section{TABLE OF CONTENTS}

Page

Preface iv

Introduction

I. Truth 5

II. Thing, Equipment, Technology

III. The Work Of Art

Conclusion

Works Cited 


\section{INTRODUCTION}

Traditional attempts at defining art consider only what we understand as works of fine art. The standards by which works of art have been evaluated include, but are not limited to, the accuracy with which the work represents its subject, the work's ability to display beauty through color combinations and line configurations, and the artist's originality of expression. In "The Origin of the Work of Art"1 Heidegger breaks with the tradition: his essay redefines art in terms of truth. For Heidegger, works of art are those things that reveal truth; in fact, artworks are the only things that are able to bring forth truth. In order to understand Heidegger's thought on art, "The Origin of the Work of Art" should be read in conjunction with his essays "On the Essence of Truth"2 and "The Question Concerning Technology". ${ }^{3}$ Read as a trilogy, the essays clarify Heidegger's understanding of truth and why this understanding is disclosed only in works of art.

For Heidegger, truth is dependent upon our experiencing it. Experiencing truth requires that we move out of our everyday way

1 Martin Heidegger, "The Origin of the Work of Art," in Martin Heidegger Basic Writings, ed. by David Farrell Krell (New York: Harper \& Row,

Publishers, 1977) pp. 149-187. All future references to this essay will be cited within the text.

2 Martin Heidegger, "On the Essence of Truth," in Martin Heidegger Basic Writings, ed. by David Farrell Krell (New York: Harper \& Row, Publishers, 1977) pp. 117-141. All future references to this essay will be cited within the text.

3 Martin Heidegger, "The Question Concerning Technology," in Martin Heidegger Basic Writings, ed. by David Farrell Krell (New York: Harper \& Row, Publishers, 1977) pp. 287-317. All future references to this essay will be cited within the text. 
of viewing things and into an open region of relatedness with them. In this open relatedness we become directed by the thing instead of forcing our directives upon it. In order to receive the thing's directives, we must engage the object with a receptive and responsive state of mind and move into its truth. Since the encounter requires that we respond to the directives given, truth becomes a co-respondence between things and ourselves. Our response is actually a co-respondence because it is grounded in the relatedness between ourselves and the thing. Thus, truth depends on our letting the thing be the thing that it is, i.e., viewing the thing as something independent from us yet related to us. Part of what a thing is includes how it exists or functions in relation to us. Therefore, the truth that we experience is not just a truth of the thing, but it is also a truth of ourselves.

Things, equipment, and technology disable us from meeting the conditions necessary for experiencing truth. Our approach toward each of these is preconditioned and predetermined by their utility for us. Consequently, we are unable to enter into an open relatedness with them where we might be directed by them. Instead, things, equipment, and technology surrender to our directives of controlling and utilizing. In such cases, we provide the directives. The event of truth, therefore, cannot happen with things, equipment, or technology.

Heidegger associates truth with language. For Heidegger, language is able to reveal truth when it reflects its origin. Language, however, has fallen victim to the technicity and utility which lay claim to things, equipment, and technology; we utilize language to 
make clear our directives. Consequently, language is only able to reveal truth when it is poetic, thereby making it an artwork. Thus, the artwork becomes the only thing in which truth happens. Heidegger sees works of art as those created things which are successful in bringing forth the event of truth through their createdness. Such created things achieve this by removing us from our everyday way of viewing things. Thus removed, we are able to be directed by things. The artwork opens a region of open relatedness, enabling us to meet the conditions necessary for the happening of truth.

Heidegger's redefining of art calls for a re-evaluation of the works which we have come to view as works of art. Heidegger does not understand artworks as being restricted to the fine arts. In fact, he may argue that some of the works which fall under this category are not really works of art at all because they do not bring about the event of truth. The theory's unwillingness to categorize artworks neatly clouds discussion and evaluation of the theory itself.

For this reason, we need to explain Heidegger's views of truth and to establish the conditions under which truth becomes accessible. Our purpose is not to evaluate Heidegger's notion of truth but to understand it so that we may determine what a true Heideggerian artwork is. Next, we must examine why things other than works of art, specifically equipment and technology, fail to meet the conditions necessary for the event of truth. Finally, it is important that we come to an understanding of how artworks are able to disclose truth in order to distinguish them as works of art. Only after this 
accomplishment can we understand why artworks are the only means of disclosing truth. 


\section{TRUTH}

At the closure of "On the Essence of Truth", Heidegger explains that "the course of the questioning [of truth] is intrinsically the way of a thinking which, instead of furnishing representations and concepts, experiences and tries itself as a transformation of its relatedness to Being."(Truth, 141) Truth therefore requires that we transform our everyday relationship with things. Heidegger views our common approach toward things as being insistent and aggressive whereby we force our directives upon the things that we encounter. Truth, by contrast, calls for a contemplative and responsive encounter wherein we let the thing direct us as to what it is. Truth is experienced; it is our entering into a relatedness with the thing we are encountering. The participation of the thing and of the discoverer in this relatedness leads Heidegger to describe truth as an event.

Truth depends upon our entering into agreement with the thing. Heidegger explains the possibility of our bringing ourselves into accordance with the thing in the following passage:

What is stated by the presentative statement is said of the presented thing in just such manner as that thing, as presented, is. The "such as" has to do with the presenting and its presented. Disregarding all "psychological" preconceptions as well as those of any "theory of consciousness," to present here means to let the thing stand opposed as object. As thus placed, what stands opposed must traverse an open field of opposedness [Entgegen] and nevertheless must maintain its stand as a thing and show itself as something withstanding [ein Standiges]. This appearing of the thing in traversing a field of opposedness takes place within an open region, the openness of which is not first created by the presenting but rather is only 
entered into and taken over as a domain of relatedness. The relation of the presentative statement to the thing is the accomplishment of that bearing [Verhaltnis] which originally and always comes to prevail as a comportment [Verhalten]. (Truth, $123 \&$ 124)

It is not clear what is happening when the thing stands opposed as object, traverses an open field of opposedness, and shows itself as something withstanding. For Heidegger, everything is present or exists within an open region. Therefore, we and the thing are present in the open region. It is only in an open region that we are able to encounter and engage with things. The open region is that place where the object is able to stand as an independent thing, and we are able to recognize it as such and consider our relationship with it. It is a clearing in that we are removed from our everyday perspective of the object; thus, the open region establishes the possibility for the object to stand opposed as object.

To let the thing stand opposed as object is to acknowledge it as something which exists independent of ourselves. In order to do this, we must resist forcing ourselves upon the thing. This means refraining from prejudgements, a preconditioned examination, ideas of utility, and any other self-imposing disposition. The thing is then able to traverse the open field of opposedness. This traversing is twofold. It includes the thing projecting itself as object; yet, the Heideggerian notion of truth involves relatedness or co-respondence between us and the thing. The thing's traversing also entails a frustrating of the field of opposedness. That is, the thing must stand as an object which is independent of ourselves yet related to us. 
These conditions establish the possibility of truth by establishing the possibility of openness. Openness occurs when we participate in and respond to the relatedness. Such involvement requires that we reflect upon what is presented. Truth requires that we respond according to the particular perspective which guides the thing. Perspective cannot refer to our point of viewing the thing, for that would be the perspective which guides us. So, our physical positioning in relation to the thing is not the perspective to which Heidegger is referring. Objects are unable to have a point of view, at least, not in the sense that we understand it. The particular perspective of the thing must refer to its relationship to us, but this relationship is not constituted by its physical positioning during our encounter with it, for physical positioning cannot guide the thing. Thus, we must look for what guides the thing as it exists.

The physical properties of a thing seem secondary to making something the thing that it is. If we take Heidegger's example of a coin (Truth, $122 \& 123$ ), we can say that it is round and made of metal. This description, however, can also be depictive of a metal charm or a metal paper weight. So, what makes a coin a coin has to be more than just its physical attributes. We must look toward that which makes the coin distinct from the charm or the paper weight. The distinction lies in what it means to be a coin; the coin has a meaning which is distinct from that of the charm or the paper weight. Thus, the coin's meaning is the perspective that guides it to be the thing that it is, a coin. However, the coin's meaning is dependent upon its relationship to us; therefore, what a thing is encompasses what it means to us. The truth of the coin is thereby 
not just a truth of the coin but also a truth of humanity.

Encountering the coin in openness is experiencing it physically and thinking about what it means to us and what that meaning says about us. Such encountering is only possible if we refrain from approaching the coin as an object of utility. Approaching the coin for its use value forces our directives upon it thereby disabling it from directing us.

The open region is then that place where we discover the thing's meaning in the context of historical humankind. Truth resides in the experience of relatedness; the statement reflects the co-respondence which occurs between ourselves and the thing. However, what things are is that which is presenced in the open region, the discoverer and the thing. What a thing is includes how it relates to us and how we relate to it. Therefore, the truth discovered is a truth of the thing and also a truth of ourselves. The possibility of this open relatedness depends upon what Heidegger calls freedom and attunement.

Heidegger explains freedom's connection with truth in the following passage:

Freedom, understood as letting beings be, is the fulfillment and consumation of the essence of truth in the sense of the disclosure of beings. "Truth" is not a feature of correct propositions which are asserted of an "object" by a human "subject" and then "are valid" somewhere, in what sphere we know not; rather, truth is disclosure of beings through which an openness essentially unfolds [west]. All human comportment and bearing are exposed in its open region. Therefore man is in the manner of ek-sistence. (Truth, 129)

Truth now becomes the revelation of what it means to exist.

Freedom is being able to look onto the interplay between things and 
ourselves. In the open region, comportment involves the thing and ourselves. Freedom lets the thing be the thing that it is by empowering it to direct us, but the thing only exists as the thing that it is in relation to us. That is, the disclosure that we encounter when we freely engage a thing in the openness of the open region is a disclosure of the thing and of our own existence. However, the disclosure depends upon the thing being free to stand opposed as the thing that it is and our being free to receive it as the thing that it is. If we freely engage the thing, we experience it in its meaning and respond to that disclosure by reflecting upon it. Through this reflection is disclosed a truth of our existence. This truth of existence is brought forth in light of the meaning of the thing. In other words, what the thing is tells a truth about our existence.

To be free means that we are open and responsive. This requires that we not force our directives upon the thing. Approaches of utility, systematizing, mastering, etc. are ways by which we force our directives upon the thing. By so doing, we miss the meaning of the thing and neglect to reflect upon what that meaning discloses. Thus, we must bring ourselves into accord with the disclosure. This accord is what Heidegger refers to as attunement. Letting beings be, freedom, is an attuning. When we let beings be, we engage them with a mind-set which brings us into accord with the disclosure. Freedom allows us to engage openly and responsively; this is attunement.

Letting being be, which is an attuning, a bringing into accord, prevails throughout and anticipates all the open comportment that flourishes in it. Man's comportment is brought into definite accord throughout by the openedness of being as a 
whole. However, from the point of view of everyday calculations and preoccupations this "as a whole" appears to be incalculable and incomprehensible. (Truth, 131 \& 132)

Hannah Arendt helps to clarify that this type of thinking requires the thinker to withdraw from the object of thought. Direct perception does not allow one to think of the being perceived, for if this is what we are doing during a direct encounter then we are really withdrawing from that encounter. ${ }^{4}$ Thinking thus entails "serenity, release, a state of relaxation, in brief, a disposition that 'lets be'." In order to attain such a disposition, we must release ourselves from any form of willing. 5

Arendt seems to be suggesting distancing from the object, if not physically then conceptually. This idea of distancing is connected to that of willing. Willing entails our positing predetermined and/or preconditioned ends onto the encounter. This occurs when our approach toward things is motivated by a predetermined purpose. If we refer back to the example of the coin, approaching the coin as payment for a debt forces our directives upon the coin. The necessary distancing and release from willing are not achieved, so we are unable to experience the coin as anything other than an object of utility. Whenever we become the focus of our encounter with things, we force the thing to subordinate itself to our particular directive. The result is our inability to encounter the thing as a whole and our unwillingness to reflect upon the disclosure. Heidegger suggests that this approach prevails with things which are familiar to us.

4 Hannah Arendt, "Martin Heidegger at Eighty," in Heidegger and Modern Philosophy Critical Essays, ed. by Michael Murray, (New Haven: Yale University Press, 1978) pp. 299 and 300.

5 Ibid., p. 303. 
Therefore, the less we know of a thing, the more readily we let it be the thing that it is. Heidegger explains in the following passage:

... where beings are not very familiar to man and are scarcely and only roughly known by science, the openedness of beings as a whole can prevail more essentially than it can where the familiar and well known has become boundless, and nothing is any longer able to withstand the business of knowing, since technical mastery over things bears itself without limit.

Precisely in the leveling and planning of this omniscience, this mere knowing, the openedness of beings gets flattened out into the apparent nothingness of what is no longer even a matter of indifference but rather is simply forgotten.(Truth, 131)

Since the coin is a familiar object of utility for us, the question arises as to whether or not it is able to disclose truth. In his discussion of the Greek temple (Origin, 168), Heidegger indicates that it is possible for objects of utility to meet the conditions necessary for the disclosure of truth. Certainly, the temple can be viewed for its use value which lies in providing shelter for the gods and a place in which to worship them. Yet, Heidegger discusses the temple's ability to disclose truth. If there is a distinction between the coin and the temple, it may rest in the fact that the temple is no longer a familiar object of utility. It seems reasonable to suggest that the ancient Greeks did not experience a disclosure of truth when they went to temple because they approached with a predetermined directive. It is possible that the temple only discloses the Greek epoch to us because we do not utilize it and are thereby able to freely engage it. Although Heidegger does not directly address this issue, the preceding passage indicates that the coin may not be free to disclose truth because we ordinarily approach it for its use value. We thereby force our directives onto the coin and fail to achieve the 
necessary distancing. It, therefore, seems to be uncommon for familiar objects of utility to disclose truth.

Truth involves the thing being discovered and the discoverer. What is discovered is a truth of existence, a truth of what the thing means and of what that meaning reveals about ourselves. Things only have meaning in the context of human existence, so Heidegger recognizes that their truth lies in their relatedness to that existence and not merely in their use value. The revelation of truth requires that we participate in the experience through reception and reflection. Our willingness to receive and to respond is as essential to the disclosure of truth as is the thing we are encountering. We, however, normally do not engage things on this level. Thus, we frustrate the event of truth. Our everyday approach toward things is one of examination, utility, or mastery. This is why artworks are essential to the revelation of truth. An artwork is a thing which enables us to look onto our existence because works of art enable us to transcend our everyday approach toward things. Before discussing how readily works of art hold fast to the conditions necessary for truth, we need to examine why things other than artworks are not successful in disclosing truth. 


\section{THING, EQUIPMENT, TECHNOLOGY}

Things, equipment, and technology are able to reveal observable and functional truth. That is, we are able to make claims about their observable properties and their usefulness. However, we are not able to enter into a co-responding relationship with them. For Heidegger, something exists with meaning. The meaning of the thing is derived from its relationship to us. So truth encompasses more than the properties of a thing; it includes that thing's meaning in the context of historical humankind. Therefore, the truth of a thing is a truth about that thing and about ourselves.

Observing alone cannot render meaning because it focuses on certain aspects of the thing thus excluding the rest of that which makes the thing what it is. Consequently, the thing is not experienced as a whole. Moreover, we tend to approach things, equipment, and technology with an eye on what each can do for us. Such an approach does not consider the thing as a whole nor does it reflect upon what the thing is as it exists. Instead, our common approach toward things, equipment, and technology is one of domination. We approach each with an eye on how we can control it so that it may serve us. As a result, we miss the meaning that things, equipment, and technology have in our existence, thereby missing the truth about them and a truth about ourselves.

"The Origin of the Work of Art" addresses the reasons why things and equipment do not reveal truth. Heidegger maintains that the three leading interpretations of the thing are an assault upon the 
thing.(Origin, 160) The first interpretation considers the thing as the bearer of traits (Origin, 155) and thereby keeps the thing too distant from us.(Origin, 157) This interpretation focuses only on the external properties of the thing, thereby removing the thing from its context, its place in human existence. If we employ our previous example of the coin to this interpretation, we encounter the coin as metal, round, small, and flat. We experience the coin in a purely observational and thereby objective sense.

The second interpretation explains the thing as the unity of what is presented to the senses (Origin, 156), which brings the thing too close to us. This interpretation results in a preoccupation with how the thing affects us in that specific encounter with it; thus, we as individuals become the sole standard of the thing's truth. We now encounter the coin as hard, smooth, and shiny. We experience the coin in a purely sensational and thereby subjective sense. Heidegger explains the result of these two interpretations in the following passage:

In both interpretations the thing vanishes. It is therefore necessary to avoid the exaggerations of both. The thing itself must be allowed to remain in its self-containment. It must be accepted in its own constancy. This the third interpretation seems to do, .... (Truth, 157)

The third interpretation views the thing as formed matter.(Origin, 157) Although this interpretation accepts things in their own constancy, Heidegger cautions that the fact that it has been taken as self-evident in modern investigation means that "it is an encroachment upon the thing-being of the thing."(Origin, 160) This last interpretation results in a preconditioning of the expectations of 
the encounter with the thing, thereby limiting our receptivity to it. By this interpretation we encounter the coin as a means of commerce. We experience the coin purely through its use value and thereby in a utilitarian sense.

Heidegger's rejection of the leading interpretations of the thing centers around their inability to receive the thing as the thing that it is. So, when Heidegger tells us that the three interpretations of the thing and combinations thereof "preconceive all immediate experience" and thereby "shackle reflection" (Origin, 160), he means that these interpretations inhibit us from entering into the openness of the open region; thus, the freedom and attunement necessary for the disclosure of truth is not achieved. Being present in the openness requires that we listen to what the thing has to reveal and reflect upon what we have heard. The product of the thing's presentation and our reflection is truth. Thus, attaining truth from the thing requires our engaging with its physical properties and the meaning of its existence.

The problem is that we readily approach things with a predetermined objective, thereby failing to bring ourselves into accord with all that they are as they exist. We are even more inclined to impose our directives onto equipment. This is because equipment is brought into existence only to meet our specific needs. Therefore, our approach toward equipment is one of utility; we encounter equipment when we need to use it. As a result, we fail to encounter what the equipment means in its usefulness.

Heidegger explains that equipment consists in controlling form and matter according to the purpose of the thing.(Origin, 157) The 
matter and form will vary depending on the equipment's intended use. The equipmental quality of all equipment consists in its usefulness.(Origin, 162) The essential Being of equipment lies in its reliability.(Origin, 163) The question is, how is truth attained through the piece of equipment? The problem of distancing which resulted from the first two interpretations of the thing also applies to equipment. Equipment can be approached by way of observation or by way of use. In the former, description, explanation, and report set us too far from the equipment to enter into the disclosure of truth. (Origin, 164) Conversely, in utility the matter of the equipment disappears into usefulness and serviceability.(Origin, 171)

The problem with merely describing, explaining, and reporting on the equipment is the same problem as the first interpretation of things. As we recall, that interpretation focused on the thing as the bearer of traits which resulted in removing the thing from its context. Observation alone also focuses on the external aspects of the equipment, thereby missing the meaning it has in our lives. The freedom which is necessary for the revelation of truth is not accomplished because we have already determined the mode of approach. For example, if we approached the equipment with the intention of reporting on it, our approach would be prestructured according to the information needed in the report. Consequently, we are not free to engage the equipment nor reflect upon it, and it is not free to present itself as the thing that it is. If we had to report on an electric wheelchair, for example, we might look for the type of metal used to construct it, the battery voltage necessary to operate it, its maximum speed, weight capacity, etc.. However, this information 
will not lead us to discover the meaning that the wheelchair has, but this meaning is as much a part of the wheelchair as are its external components.

Approaching equipment for utility results in a problem which is similar to that of the third interpretation which views the thing as formed matter. As with this interpretation, utility focuses on our predetermined purpose for the encounter. Using the wheelchair fails to lead us to its truth because in our using the chair we forget its composition. That is, we are focused on how well it accomplishes its purpose of moving us from place to place. In addition to limiting the freedom necessary for the openness of the open region, both observation and utilization of the equipment neglect to reflect upon it. If the truth of the wheelchair rests in its being the thing that it is as it exists then its truth is not just compositional or functional; it is also meaningful. The wheelchair means freedom of movement and a sense of independence for the person who needs it, and this meaning is accomplished through its structure and function. As observer and user we are imposing and nonreflective; therefore, we miss the whole of what the wheelchair is as it exists.

The two approaches toward equipment, observation and utility, produce the same obstacle to truth as do the three interpretations of thing as the bearer of traits, the unity of what is presented to the senses, and formed matter. The obstacle rests in our imposing directives upon the encounter instead of allowing the encounter to direct us. Of course, equipment lends itself to subjective ends more readily than do mere things. This preoccupation with predetermining, preconditioning, and prescribing inhibits the 
freedom which is essential to the disclosure of truth. Such a danger peaks in the area of science and technology, where ordinary preoccupations are easily heightened to a preoccupation with mastering.

Harold Alderman points out that Heidegger's problem with science and technology is that they are not Being-oriented. Our mistake is that we take control, thereby bringing Being before ourselves and relating it and beings to ourselves. ${ }^{6}$ Scientific projection determines the manner in which facts must conform to the scientific investigation. Such projection serves to determine a sphere of Being and force it into a definite realm of Being. ${ }^{7}$ Since experiments are restricted to humanly imposed directives, modern science has come to depend on our confirmation of the hypothesis, for we ourselves determine the conception of fact, the experiment, and the conformation. The institutionalization of scientific procedures explicitly grants the power and authority officially to manage and objectify Being as an object of research. ${ }^{8}$ In the final analysis we see that the objectivity of Being in science implies the subjectivity of human beings. ${ }^{9}$

It is important to note that scientific thought is not being attacked as such. Rather, it is our fidelity to it as disclosing the truth that is dangerous. The measurable and explicable nature of beings is but a part of their entirety. The scientific approach and its findings

6 Harold Alderman, "Heidegger's Critique of Science and Technology," in Heidegger and Modern Philosophy Critical Essays, ed. by Michael Murray (New York: Yale University Press, 1978) p. 37.

$7 \quad$ Ibid., p. 38.

8 Ibid., p. 40.

$9 \quad$ Ibid., p. 41. 
are valid only in so far as they are recognized as revealing a limited aspect of the whole. When this is not the case, the freedom necessary for the disclosure of truth is not accomplished and "only it accomplishes for humanity that distinctive relatedness to being as a whole."(Truth, 129)

The scientist is blinded by his/her ability to fit the object of his/her investigation neatly into an equation that is within his/her control (i.e., posited by him/her, calculated by him/her, and resolved by him/her). Consequently, the scientist empowers him/herself with the determination of Being. This is a problem because "truth is disclosure of beings through which an openness essentially unfolds."(Truth, p. 129) The scientist, as scientist, is not in attunement with the disclosure of truth; he/she is not open and responsive so that he/she might bring him/herself into accord with the disclosure. Such human insistence sets the ground for errancy.(Truth, p. 135)

The scientific method's limitations on truth are slightly different from those of the thing and of equipment. The reason for the difference is that the scientific method explicitly concentrates on a given aspect of the scientific object. The problem is that science accepts its truths as the truth of the totality of the scientific object. The scientific method necessitates a preconditioned approach toward the object under investigation, and the directives of the approach have been predetermined by the scientist, thus violating the conditions necessary for a proper encounter. The freedom necessary for the object to present itself as the thing that it is cannot be established. 
Likewise, the scientist is not free to be directed by the object. The scientist is not in attunement with the disclosure of truth because he/she is not of an open or reflective state of mind. Rather, the scientist projects conditions and limitations onto the scientific project, thereby restricting its ability to reveal its totality and disabling the scientist's ability to encounter the object in its totality. Since the scientist isolates aspects of the scientific object, establishes him/herself as the standard of measure, and preconditions the encounter, the scientific approach is exemplary of the inadequacies of the three leading interpretations of the thing. Heidegger talks about this type of approach toward things in the following passage:

... humanity replenishes its "world" on the basis of the latest needs and aims, and fills out that world by means of proposing and planning. From these man then takes his standards, forgetting being as a whole. ... He is all the more mistaken the more exclusively ha takes himself, as subject, to be the standard for all beings.(Truth, 134 \& 135)

Edward Ballard attempts to clarify the problem with science by detailing the scientific method. He explains that the scientific approach requires a "working over" of the object. Through this working over the object is transformed by being removed from the world in which it exists and by undergoing imposed sensitization.10 The transformation enables the scientist to employ a mathematically objective method, thus unveiling objective nature. Ultimately, the object is reduced to the directives willed by the scientist.11 The evaluation of the object is incomplete because there is no

10 Edward Ballard, "Heidegger's View and Evaluation of Nature and Natural Science," in Heidegger And The Path Of Thinking, ed. by John Sallis (Pittsburgh: Duquesne University Press, 1970) p. 42.

11 Ibid., p. 43. 
consideration of the object as it exists as worked over. Thus, the scientific process falls out of perspective in that it is not recognized as a specified process but as a process which is capable of rendering evaluation of the totality.12

The problem is not just that we do not consider the object as "worked over" by the scientific approach. It is also that we never consider the object before it is worked over. Thus, we neglect what the object means to our existence. The scientific approach also fails to look onto itself. In other words, the scientist does not reflect on the object to discover what it means to the scientist or to humanity as worked over. The imposing nature of science along with its vulnerability to human directives empowers the scientist as the master of things. This is problematic in regard to the disclosure of truth because revelation requires freedom to let the being reveal itself and an open region in which the scientist and the object engage in relatedness. Both criteria are overshadowed by the mere nature of the scientific method. The open region requires that the object be free to direct the encounter and the scientist be free to bring him/herself into accord with those directives. The scientist must be open and responsive in this encounter. Science, however, requires that the scientist impose the directives of the encounter and force the object into accord with those directives. A logical outgrowth of the scientific approach is technology. Our desire to force our directives onto things is never more tempted than in the area of technology. 
In "The Question Concerning Technology" Heidegger explains that the revealing that rules in technology is a challenging of things (Technology, 296), the chief characteristics of which are to regulate and to secure. Thus, objects come to be viewed as standing reserve, things awaiting further ordering (enframing).(Technology, 298) The ordering and regulating of objects is in direct opposition to the object giving directives, for the technician forces his directives onto the object through his ordering. In technology, we are unable to encounter the object as a whole because we come to pursue only that which is revealed in ordering and derive all our standards on this basis (destining) (Technology, 307), thus driving out every other possibility of revealing.(Technology, 309)

Man stands so decisively in attendance on the challenging-forth of enframing that he does not grasp enframing as a claim, that he fails to see himself as the one spoken to, and hence also fails in every way to hear in what respect he ek-sists. .... Where enframing holds sway, regulating and securing of the standingreserve mark all revealing. They no longer even let their own fundamental characteristics appear, namely, this revealing as such. Thus the challenging-enframing not only conceals a former way of revealing, bringing-forth, but it conceals revealing itself and with it that wherein unconcealment, i.e., truth, comes to pass. Enframing blocks the shining-forth and holding sway of truth.(Technology, 308 \& 309)

Heidegger sees technology as inherently restricting the revelation of truth. The problem with technology is similar to that of the scientific method because technology also requires that we set the directives of the encounter and force the object to meet our predetermined objective. Truth, however, requires that we be free from willing our directives onto the encounter so that the object is free to direct us. The revelation of truth is not merely restricted 
through technology, but it is transformed. The ordering and regulating of things is not a truth present in them; it is wholly posited onto them by our directives. More specifically, the nature of technology requires that we encounter things with a predisposed state of mind. This disposition restricts any possible disclosure of truth except for the thing's utilitarian value to us. Consequently, we neglect to recognize the controlling nature of technology and are unable to enter into the openness of the open region. The nature of technology heightens this approach toward things by enticing us to strive for greater control over them.

Harold Alderman attempts to further explain the danger that Heidegger sees as inherent in technology. He maintains that technology is not responsive and contemplative but domineering and challenging. ${ }^{13}$ In modern technology we posit ourselves as a being over nature instead of a being within nature; there is no mode of letting things be.14 Technological thought "provokes man to be the being who makes nature yield its resources to him and which places man in a position to be the provacateur of nature." Thus, technology holds sovereignty over beings and over all modes of uncovering beings. 15

Through technology we have come to focus on the efficient cause, thereby viewing cause as that which makes or produces an

\section{Alderman, op. cit., p. 44.}

14 Ibid., p. 48. Alderman illustrates by contrasting a motorboat with a sailboat. A motorboat uses energies to overcome the water. The currents and winds are seen as obstacles which must be surmounted. Motorboating attempts to dominate the water. In sailboating, however, one utilizes currents and winds in order to move across the water. The sailboat depends on the wind and current, and this dependency is recognized. Thus, the sailboat is a thing of the water.(p. 49)

15 Ibid., p. 49. 
effect. Consequently, "man as the maker and producer occupies the center of causality: cause signifies the instrumentality of man." Through technology we have therefore come to view Being as either ends or means. Technicians choose ends and develop techniques which efficiently achieve their goals. In turn, these ends become means to further humanly posited directives. The technological doctrine of Being ultimately subordinates Being to the goals and purposes of the technician. ${ }^{16}$ Thus, he/she positions him/herself as the determinant of the nature of Being by viewing beings as nothing more than materials waiting to be utilized as he/she wills. The danger in technology lies in our attitude towards it. ${ }^{17}$ Through technology we come to view things exclusively in terms of how we can direct them to better serve us. This attitude leads us to believe that a thing's use value is all that the thing is. The technological object, like the scientific object, is not encountered as a whole because it is not allowed to direct the encounter, so its truth is not revealed.

We seek to control through manipulation and through utility. Things, equipment, and technology readily fall into our service and thus under our directives. The result is a shadowing of the openness of the open region necessary for the disclosure of truth. In this shadowing the thing, equipment, or technology is not allowed to present itself as it exists but instead is viewed by way of our subjective ends.

16 Ibid., p. 45.

$17 \quad$ Ibid., pp. 47 and 48. 
Heidegger thinks that our everyday approach toward things, equipment, and technology reveals only objective or subjective truths by focusing on how the thing appears to us, affects us, or serves us. Neither of these, however, is reflective of his understanding of truth because they are ways in which we force our directives onto the thing thereby inhibiting the thing from directing us as to what it is. For example, when we encounter things, equipment, or technology in an examinatory way, we are only able to discover factual aspects of their being. We are able to observe construction, size, material consistency, and a multitude of other objectified characteristics. The result is a failure to discover the thing as it exists in our lives.

Similarly, when we encounter things, equipment, or technology by way of utility, we are only able to discover the useful aspects of each. Truth is then measured by how well the thing, equipment, or technology serves us in its functioning. This subjective approach and the former objective approach "preconceive all immediate experience" (Origin, 160) which keeps us from entering into the openness of the open region where things are free to direct us and we are free to bring ourselves into accord with their directives. Consequently, the disclosure of truth does not occur during our encounter with things, equipment, or technology. The difficulty involved in experiencing truth is displayed in the following passage:

... where beings are not very familiar to man and are scarcely and only roughly known by science, the openedness of beings as a whole can prevail more essentially than it can where the familiar and well-known has become boundless, and nothing is any longer able to withstand the business of knowing, since 
technical mastery over things bears itself without limit.(Truth, 131)

At the close of "The Question Concerning Technology" Heidegger suggests that the techne of art is a single manifold revealing which yields to the holding sway and the safekeeping of truth. He asks, "Could it be that revealing lays claim to the arts most primally ...?(Technology, 316) "The Origin of the Work of Art" answers this question. Art is able to accomplish the freedom and attunement required for the transcendence which is essential to the revelation of truth. The work itself establishes the openness of the open region necessary for the disclosure. Finally, art is not only able to disclose truth, it preserves it. 


\section{THE WORK OF ART}

Our discussion thus far has lead us to the idea that works of art hold a privileged position in the bringing about of the event of truth. Unlike things, equipment, and technology, the artwork holds open the open region which is necessary for the event of truth. Thus emerges the Heideggerian interpretation of a work of art. Artworks are those things which bring forth the event of truth. According to Heidegger, a work is only a work of art when it sets up a people's historical existence, enables us to remove ourselves from our commonplace routine and move into the disclosure of truth, and finds its essence in poetry.

Heidegger understands poetry as the founding of truth as bestowing, grounding, and beginning.(Origin, 186) Poetry is privileged in the arts because it is language which first gives presence to beings. Language first brings forth the historical world of a people and preserves it and the earth by naming and presencing.(Origin, $185 \& 186$ ) This is why language is often related to the disclosure of truth in the Heideggerian sense. Walter Biemel explains that meanings are not assigned to words; rather, words are able to manifest meanings. ${ }^{18}$ Our previous discussions have concluded that meaning, rather than function, is what Heidegger understands as truth. For example, when we approached the coin in terms of utility, we found that only its use value, or function, as a

18 Walter Biemel, "Poetry and Language in Heidegger," in On Heidegger and Language, ed. by Joseph Kockelmans (Evanston: Northwestern University Press, 1972) p. 70. 
coin was revealed. Yet, the coin is more than merely a means of commerce. The possibility of our encountering the truth of the coin, however, depends upon our encountering the coin in an open region where it is free to direct us and we are free to be directed. In our previous discussion of the coin, we found that we were unable to encounter the coin freely when we imposed our directives of utility upon it, because this approach brings us too close to the coin.

A.F. Lingis suggests that language gives birth to poetry and technique by opening a region in which the clearing of Being is brought to light.19 There exists a distance between the speaker and that about which he/she speaks. The latter undergoes a manifestation through the discourse. The discourse is about the world.20 However, Heidegger tells us that although language presences the lighting of beings, this goes unnoticed in language.(Origin, 186) George Steiner helps to explain that "ordered verbal discourse" is unable to overcome metaphysical constraints. Art, however, is able to overcome such constraints because it "pierces to the core of things". Hence, in works of art truth comes into being and achieves realization and self-possession. ${ }^{21}$ Heidegger explains the need for art and its connection to poetry in the following passage:

The essence of art is poetry. The essence of poetry, in turn, is the founding of truth. ... Art lets truth originate. Art, founding preserving, is the spring that leaps to the truth of beings in the work.(Origin, 186)

19 A. F. Lingis, "On the Essence of Technique," in Heidegger and the Quest for Truth, ed. by Manfred S. Frings (Chicago: Quadrangle Books, 1968) p. 134. 20 Ibid., p. 136.

21 George Steiner, Martin Heidegger (New York: The Viking Press, 1978) p. 132. 
The shift is thus made from language to poetry, or more specifically the poetic. Heidegger understands the poetic in the Greek sense of poiesis. Poiesis refers to occasioning and presencing, a bringing-forth. Heidegger explains that "bringing-forth comes to pass only insofar as something concealed comes into unconcealment."(Technology, 293) When the speaker's world overshadows the world of the object of the disclosure, freedom and attunement stray and language becomes susceptible to utilitarian ends. Artworks, on the other hand, essentially and necessarily hold fast to that which is presenced and are thereby able to entice a perspective which draws us into a world other than our own. Language is also susceptible to an evolutionary process. The development of language often strays from its origin. Hence, language and the meaning conveyed by its use cannot be considered constant. The artwork, however, is captivating. It captures a meaning and enables it to endure through time. The artist receptively captures truth and expresses and guards it in and through his/her creative production.

The fact that an artwork is created is part of what Heidegger calls the workly character of the work.(Origin, 178) This creation requires mastery, craftsmanship or techne. Heidegger explains the meaning of techne in the following passage:

The word techne denotes rather a mode of knowing. To know means to have seen, in the widest sense of seeing, which means to apprehend what is present, as such. For Greek thought the essence of knowing consists in aletheia, that is, in the revealing of beings. It supports and guides all comportment toward beings. ... to create is to let something emerge as a thing that has been brought forth. The work's becoming a work is a way 
in which truth becomes and happens.(Origin, 180)

Heidegger concludes that truth has to happen in such a thing as something created.(Origin, 180)

Walter Biemel explains that artists possess a kind of knowledge which "looks toward something not yet present in such a way that it makes it possible to give form to the work." It is this knowledge which distinguishes the artist from the handworker and technician. ${ }^{22}$ To bring Biemel's explanation a step further, the artist's possession of such knowledge is necessary but so too is the created product. Jacques Taminaux offers that Heidegger rejects artworks being approached in terms of matter and form because these are concepts which are adjusted to utensils. An approach in terms of representation is also rejected because "the present-at-hand of everyday things operates as a standard."23 Taminiaux's

interpretation is reminiscent of our discussion of equipment and technology. The creative process surrounding equipment and technology focuses on producing a thing of servicability or utility, neither of which requires the apprehension of what is present. In fact, the objective which usually guides the creation of equipment and technology is how well the thing produced will meet our needs or its utilitarian function. The need for the thing is known but this knowledge does not necessitate a knowledge of what its usability or utilization means.

22 Walter Biemel, "Elucidations of Heidegger's Lecture The Origin of Art and the Destination of Thinking," in Reading Heidegger Commemorations, ed. by John Sallis (Bloomington: Indiana University Press, 1993) p. 372.

23 Jacques Taminiaux, "The Origin of The Origin of the Work of Art," in Reading Heidegger Commemorations, ed. by John Sallis (Bloomington: Indiana University Press, 1993) p. 402. 
According to Henri Birault, Heidegger, in discussing techne, substitutes the duality of world and thing for matter and form. The issue is one concerning the "operative" character of truth. ${ }^{24}$ Birault's idea of an operative character of truth is essential to understanding Heidegger's idea of techne. The product of techne is a thing which reveals truth. Since the disclosure of truth is dependent upon the fulfillment of certain conditions, techne produces a thing which enables the fulfillment of the conditions necessary for the disclosure of truth. Birault's distinctions among matter and form and world and thing are important ones. Matter refers to the raw material which is already existent. Form refers to structure, shape, or construction, all of which are secondary to the essential characteristic of techne, which is the revelation of beings or the disclosure of truth. The thing, however, is that which is brought into presence by the creating process of techne. The produced thing is a thing which discloses truth.

According to Heidegger, creation, in relation to techne, is the bringing forth of the strife between earth and world (Origin, 181), and this strife is essential to the disclosure of truth.(Origin, 177) Earth and world are difficult concepts to establish mainly because Heidegger does not understand them in terms of their ordinary meaning. Yet, he neglects to establish explicitly how earth and world are to be understood. Since both earth and world are crucial to a thing being an artwork, we need to attempt to come to an understanding of what each refers to for Heidegger.

24 Henri Birault, "Thinking and Poetizing in Heidegger," in On Heidegger and Language, ed. by Joseph Kockelmans (Evanston: Northwestern University Press, 1973) p. 162. 
Heidegger describes earth as follows:

It [physis] illuminates also that on which and in which man bases his dwelling. We call this ground the earth. What this word says is not to be associated with the idea of a mass of matter deposited somewhere, or with the merely astronomical idea of planet. Earth is that whence the arising brings back and shelters everything that arises as such. In the things that arise, earth occurs essentially as the sheltering agent.(Origin, 169) $\ldots$ Upon the earth and in it, historical man grounds his dwelling in the world.(Origin, 171)

R. Raj Singh interprets earth as the companion to and ground of the world.25 However, Joseph Smith describes earth as being rooted in untruth, a concealment, a withholding, ${ }^{26}$ a principle opposing world.27 He explains that we are of the earth and not merely on the earth. Therefore, earth is not merely a dwelling place; it is dwelling itself. ${ }^{28}$ Of course, earth is most easily understood as nature and all that comes from it. However, none of these descriptions seems to reflect completely Heidegger's understanding of earth.

Heidegger describes earth as that upon which and within which we dwell; thus, earth seems to include nature and that which comes from it. Yet, Heidegger also says that it is that upon which we ground our dwelling in the world. In order for earth to provide a ground for dwelling in the world, it must have a constant aspect, for grounding requires a degree of stability, but nature is fluctuating. That is, change is essential to nature. Consequently, Heidegger must

25 R. Raj Singh, "Heidegger and the World in an Artwork," in The Journal of Aesthetics and Art Criticism, vol. 48 no. 3, Summer 1990, p. 220.

26 Joseph Smith, "In-the-World and On-the-Earth: A Heideggerian Interpretation," in Heidegger and the Quest for Truth, ed. by Manfred S. Frings (Chicago: Quadrangle Books, 1968) p. 191.

27 Ibid., p. 187.

28 Ibid., p. 200. 
mean more than nature itself when he speaks of earth. He hints at the earth's constant aspect when he refers to the earth as the "resolute foundation" upon which the world grounds itself.(Origin, 173) Earth thereby includes that stability through which nature's changes and our establishing of a world are made possible.

Heidegger also describes earth as that which comes forth and shelters. It seems that earth has the quality of presencing in the sense of bringing forth into existence. Thus, part of what earth is includes beings, but it must also include the Being which makes the existence of beings possible. The coming forth of Being and beings is made possible by and constitutes the earth. The beings that emerge shelter in the sense of covering and in the sense of protecting Being. Earth provides the possibility for world yet has no meaning without world. Earth and world are co-dependent in that world needs the grounding of earth and earth needs the acknowledgement of world. Heidegger explains in the following passage:

The earth cannot dispense with the open region of the world if it itself is to appear as earth in the liberated surge of its selfseclusion. The world in turn cannot soar out of the earth's sight if, as the governing breadth and path of all essential destiny, it is to ground itself on a resolute foundation.(Origin,173)

For Heidegger, world provides the context within which things find meaning. A thing's meaning is determined through our relationship with it. This relationship is established through world. Heidegger describes world as the following:

World is never an object that stands before us and can be seen. World is the ever-nonobjective to which we are subject as long as the paths of birth and death, blessing and curse keep us transported into Being. Wherever those decisions of our 
history that relate to our essential being are made, are taken up and abandoned by us, go unrecognized and are rediscovered by new inquiry, there the world worlds.(Origin, 170)

Joseph Smith interprets world as not meaning existential living. He claims that it is not our environment or nature, and it is not a world of substance or essence. Also, world does not refer to the subject region of a particular individual.29 If we accept what world is not, assuming for now that we do, we must inquire as to what world is. Joseph Kockelmans suggests that world is the existential dimension of humankind through which all relationships become possible and within which we encounter beings. ${ }^{30}$ This explanation of world seems to be reflective of Heidegger's understanding.

The notion that world is a dimension is a helpful means of understanding world. Heidegger tells us that we dwell in the world, so world must include the scope of our existence. However, it is not clear that existence is enough, for Heidegger says that objects do not have a world and that world is nonobjective in character. Heidegger tells us that the peasant woman "has a world because she dwells in the overtness of beings."(Origin, 170) Objects, however, do not seem to dwell at all; they cannot establish relationships or make decisions. Therefore, objects do not have a world but must rely on belonging to our world, and how we see them depends on how they are revealed in world. Through our decision-making and living, we give things a context, a meaning, a world in which they can exist. Thus, world refers to the realm of existence in which human choices are made possible and establish themselves. World becomes essential for the

$29 \quad$ Ibid., p. 185.

30 Kockelmans, op. cit., p. 170. 
disclosure of truth because the disclosure involves establishing a relationship between ourselves and other beings.

Smith suggests that the worlding of the world is one of disorder and chaos. ${ }^{31}$ Although disorder and chaos may result from decisionmaking, tension seems more accurately to describe the worlding of the world. The tension exists between the stability of earth and the evolution of world and between ourselves and other beings. The result is not absolutely or necessarily chaos and disorder. Sing more accurately points out that the world worlds in a distinct way during a distinct historical era but that our relation with our world is historically constant. 32

If world creates or opens the possibility for decision-making then that possibility must always exist, and as long as we make decisions through that possibility, our world worlds. The worlding of the world is distinct in that different peoples at different eras of history engage in living differently. So, world has an evolving aspect as well as a constant aspect. As peoples have worlds, so too do individuals. For, it follows that if the criteria for the worlding of the world is the grounding of earth, the possibility for decision-making, and the actual decisions of living, individuals as well as groups of individuals have distinct worlds. It seems that part of Smith's interpretation of what world is not is mistaken, for world can refer to the subject region of a particular individual. Heidegger hints at the collective and singular possibility of world in his discussions of the historical world of the ancient Greeks set up by the Greek temple

31 Smith, op. cit., p. 186.

32 Sing, op. cit., p. 219. 
(Origin, $169 \& 170$ ) and the world of the peasant woman set up in the Van Gogh painting (Origin, 163). By setting up a world, the artwork distances us from our everyday world in which we direct things. The work draws us into the world that it sets up, thus freeing us to be directed. As the worlding of the world evolves in the context of world, so must the worlding of the individual's world evolve within the context and against the backdrop of an historical people.

The relationship of earth and world is one of interplay and codependence. Our emergence on the earth instigates the worlding of world. World is dependent upon human existence. Earth is a source for and grounding of existence and activity, but these are only possible once we arrive on the scene. It is at that instant that the worlding of a world begins. Although earth exists regardless of our presence, it does so without being part of a world, without meaning.

By setting up a world and setting forth the earth, the work of art instigates and accomplishes this strife.(Origin, 173) By so doing, the work holds the unconcealedness of beings as a whole.(Origin, 177) According to Heidegger, strife between earth and world is essential to the disclosure of truth.(Origin, 177) In a state of strife each struggles to surmount the other. In the strife between earth and world each raises the other "into the self-assertion of their essential natures."(Origin, 173) Strife refers to the tension which exists between earth and world. Things attempt to emerge as the things that they are as we attempt to force our directives onto them. In our world, we succeed in directing things, thus, eliminating the strife. The work of art is able to bring forth the strife by setting up a 
world in which we cannot actually force our directives onto things. In doing this, the artwork distances us from things yet places them in a context. This distancing enables us to enter into an open region where things are free to direct us and we are free to bring ourselves into accord with those directives. The artwork thereby accomplishes the conditions necessary for the disclosure of truth.

Artworks create a medium (open region) through which truth may freely reveal itself. In essence, a work, through its creation, presences the truth of beings as they exist. The creative process accomplishes the disclosure of truth by establishing an open region where the strife between earth and world occurs. The work itself stands in openness and lights the strife, thus making it accessible to us. Thus, Heidegger maintains that the two essential features of the work-being of an artwork are the setting up of a world and the setting forth of the earth; they are never separated.(Origin, 172)

Artistic creation is the bringing forth of the strife between earth and world. The work is the being brought forth which expressly brings forth the openness of beings.(Origin, 181) Where the strife of earth and world happens, lighting and concealing move apart thus opening a region for the conflict.(Origin, 180) Heidegger explains lighting as the following:

This open center is therefore not surrounded by beings; rather, the lighting center itself encircles all that is, ... Beings can be as beings only if they stand within and stand out within what is lighted in this lighting. Only this lighting grants and guarantees to us humans passage to those beings that we ourselves are not, and access to the being that we ourselves are. Thanks to this lighting, beings are unconcealed in certain changing degrees. And yet a being can be concealed, as well, only within the sphere of what is lighted. Each being we encounter and 
which encounters us keeps to this curious opposition of presencing in that it always withholds itself at the same time in a concealedness.(Origin, 175)

Lighting happens as the double concealment of refusal and dissembling. When presence only is known, the concealment is one of refusal. However, when the being presents itself as other than it is, as semblance, the concealment is in the form of dissembling.(Origin, $175 \& 176$ ) Unconcealment is the happening of truth.(Origin, 176)

Joseph Kockelmans attempts to clarify Heidegger's thought by suggesting that as a process of truth, Being only comes to pass in a "there". This coming to pass is not dependent on us but on Being's spontaneity in e-mitting itself among beings. The "there" of Being is the domain in which Being illuminates beings as what they are. Being therefore takes the initiative. Since Being itself is not a being, it withdraws itself as it reveals beings. Hence, the only way in which we can grasp Being itself is for us to understand Being as nonBeing. ${ }^{33}$ In relation to artwork, the work is the there, the place in which things can direct us as to what they are. At the same time, we lose sight of the work itself being a thing.

George Steiner adds that the essence of "thereness" and of meaning which a work of art reveals is contained within the work. It is embodied in the substance of the thing and therefore cannot be externalized or extracted from the work. This is the concealing nature of a work of art. Simultaneously, the work unconceals by its articulate and radiant projection of the manifestation of Being. The

33 Kockelmans, op. cit., 175. 
work conserves Being and gives it a dwelling and sanctuary.34 The eternal strife within the work is one between hiddenness and exhibition. It occurs because of the absence of the actual object and its intense presence in the work.35

Heidegger tells us that concealment refers to the not yet experienced domain of Being.(Truth, 133) Thus understood, Kockelmans' explanation of the nature of concealment is acceptable. If Being brings forth the being as it is then Being itself must give way to that which is brought forth. Although Steiner's explanation of unconcealment is sensible and consistent with the double concealment of refusal and dissembling, it is not certain that this is all that Heidegger means by concealment. When discussing the Greek statue of the god, Heidegger claims that the statue becomes the god.(Origin, 170) This claim does not recognize a distinction between the work and the actual being of its subject matter. The statue sets up the world of the god and the people who worship him. In so doing, the statue embodies the truth of the god. Although the statue and the god are not the same being, the truth of each is the same. The statue itself as a thing, a being, has no distinct meaning. As a work of art, its meaning as a thing gives way to the truth it embodies. Hence, Steiner's explanation of concealment is less adequate than Kockelman's.

An explanation of concealment which should be avoided associates earth with concealment. C.D. Keyes offers that, in the strife between earth and world, truth expresses itself through the

\footnotetext{
34 Steiner, op. cit., p. 134.

35 Ibid., p. 135.
} 
world-earth dialectic. In this dialectic earth's tendency is one of concealment and world's tendency is one of openness. Through this dialectic, the work expresses truth and allows truth to express itself. 36

Keyes' idea of the world-earth dialectic is acceptable until it associates earth with concealment and world with unconcealment. Both earth and world are essential to the strife. It is the tension within the strife that instigates each to rise forth. We have established that earth and world are co-dependent. If they cannot be separated yet truth is able to emerge from their union, it is a mistake to understand them in polarized terms of concealment and unconcealment. Heidegger cautions that "the world is not simply the open region that corresponds to lighting, and the earth is not simply the closed region that corresponds to concealment."(Origin, 177)

Truth emerges from the strife between earth and world; however, lighting and concealing are also in strife. World can conceal earth, as we have seen in our discussion of technology and equipment, by overshadowing the earth aspect. Likewise, earth can conceal world, as we have seen in our discussion of the thing and equipment, by overshadowing the world aspect. Therefore, earth and world share in the lighting and concealing and are both essential to the event of truth (unconcealment). By instigating the strife between lighting and concealing, the artwork is able to disclose truth by disallowing either from overshadowing the other. Yet, the strife causes both lighting and concealing to emerge, much in the same way as it does with earth and world. The work thereby brings about the 
revelation of the essence of a being (Origin, 178), where and how world and earth interplay. The unconcealment is "a disclosure of a particular being, disclosing what and how it is."(Origin, 164)

Steiner attempts to explain the world/earth interplay and how it discloses truth. He explains that in the artwork the world of beings is envisioned on more absolute and nonpragmatic terms. The presentness in things is nonutilitarian but has its own integral, "ecstatic" authority. The mode of existentiality fundamental to the presentness of things exists in and through a work of art. The work of art is disinterested creativity, which is dependent upon matter (wood, stone, pigment, etc.). In this sense, the world worlds in and through works of art.37

Paul Schumacher and Wayne Owens explain why the disclosure is more accurately described as an event. Schumacher maintains that the artwork is more accurately described as an event than as an object because something new and significant is being brought to bear on the old and familiar.38 Through the artwork "the individual, society, and the aesthetic object are brought together in a way that elucidates existence".39 The artwork expresses beings and relationships among beings.40 Owens describes the event as presencing, which is linked with emerging and living.41 The event concerns "the historical relations between things, thoughts, and

37 Steiner, op. cit., p. 133.

38 Paul Schumacher, "Art for Existence's Sake: A Heideggerian Revision," in Journal of Aesthetic Education, vol. 24 no. 2, Summer 1990, pp. 86 and 87.

39 Ibid., p. 84.

$40 \quad$ Ibid., p. 85.

41 Wayne Owens, "Heidegger's Philosophy of Art," in British Journal of Aesthetics, vol. 29 no. 2, Spring 1989, p. 132. 
acts." 42 The artwork removes us from the ordinary experience or view of things and into an extraordinary experience or view of things.43 Heidegger terms the characteristic of the work talked about by Steiner, Schumacher, and Owens as displacement.

The work's ability to "cut all ties to human beings" enables the work to transport us out of the realm of the ordinary.(Origin, 183) The work cuts all ties to human beings in that it does not fall subject to our directives. The work's ability to direct us accomplishes what we have been referring to as distancing. The work distances us by transporting us out of our ordinary encounter with things in which we impose our directives and into a new encounter in which we are directed. Heidegger explains that:

To submit to this displacement means to transform our accustomed ties to world and earth and henceforth to restrain all usual doing and prizing, knowing and looking, in order to stay within the truth that is happening in the work. Only the restraint of this staying lets what is created be the work that it is.(Origin, 183)

The artwork opens this possibility and opens the truth of beings. Thus, openness occurs within and without the work, the openness is contained therein and the work is therein contained.

Owens explains that displacement requires a release of all previously established standards of the way things are seen and interpreted. A new perspective on things is thereby discovered.44 Walter Biemel adds that the artwork transposes us into a world or opens up a world that is not determined by the absolute dominance

$\begin{array}{ll}42 & \text { Ibid., p. } 135 . \\ 43 & \text { Ibid., p. } 137 . \\ 44 & \text { Ibid., p. } 131 .\end{array}$


of our subjective world.45 And Schumacher suggests that displacement is made possible because the work keeps us from doing what we usually do thus keeping us within the happening of the work. 46

These three interpretations are helpful but need expansion. Heidegger tells us that the work is able to transport us because it cuts all ties with human beings. Truth, however, requires corespondence between ourselves and the thing, so some relationship needs to exist. Truth also requires that the thing be allowed to stand opposed as object. We have concluded that to let the thing stand opposed as object means to view the thing as something independent of ourselves, yet related to us. So, a work of art's ability to cut all ties with human beings can refer to its ability to repel our inclinations of incorporating it into our world. The work itself sets up a world, and this is the place to which we are transported. We remain part of the encounter but not as the giver of directives; instead, we are directed. Through the work we are removed from our everyday manner of encountering things and drawn into a new experiencing of things. By our transcending our world, the work is empowered to disclose its truth because it disables us from forcing our directives upon the disclosure, but instead forces us to let it guide us into the disclosure. A thing is a work of art because it is able to maintain an uninterrupted and steadfast being what it is (self-subsistence).(Origin, 182) Therefore, it seems that the ability of

\footnotetext{
45 Biemel, "Elucidations of Heidegger's Lecture the Origin of Art and the Destination of Thinking," op. cit., p. 381.

46 Schumacher, op. cit., p. 85.
} 
a work to let beings be the things that they are despite our insistence is inherent in all things which are works of art.

Heidegger employs Van Gogh's painting of shoes to illustrate the happening of truth in an artwork. Heidegger describes the truth disclosed by the painting in the following passage:

From the dark opening of the worn insides of the shoes the toilsome tread of the worker stares forth. In the stiffly rugged heaviness of the shoes there is the accumulated tenacity of her slow trudge through the far-spreading and ever-uniform furrows of the field swept by a raw wind. On the leather lie the dampness and richness of the soil. Under the soles slides the loneliness of the fieldpath as evening falls. In the shoes vibrates the silent call of the earth, its quiet gift of the ripening grain and its unexplained self-refusal in the fallow desolation of the wintry field. This equipment is pervaded by uncomplaining worry as to the certainty of bread, the worldless joy of having once more withstood want, the trembling before the impending childbed and shivering at the surrounding menace of death.(Origin, 163)

C.D. Keyes draws a definition of artwork from Heidegger's discussion of the Van Gogh painting. The painting, according to Keyes, is an artwork because it is "a truthful disclosure that reveals what the shoes are in their function"; it reveals the Being of beings. The thing character of the painting takes a secondary position to its functional character.47 The work character of the painting establishes a world which Keyes defines as "the ontological context in which a functional-instrument is." 48

It seems reasonable to assume that Heidegger would agree with this definition. Although the thing character and the work character of the painting are essential to its ability to bring forth the

$47 \quad$ Keyes, op. cit., p. 68.

48 Ibid., p. 69. 
event of truth, it is the event itself, our being transported into a new world where we are able to experience things in their relationship with us, which enjoys first position. As we discovered in our discussion of truth, things have meanings only because they exist within the context of a world. The painting establishes the shoes as existent and as existing in a context, a world. By setting up a world and setting forth the earth, the painting unconceals the truth of the peasant shoes. The work distances us from the everyday context of the shoes, thus enabling us to let them be what they are, yet, draws us into the world to which they belong, a new context, the world of the peasant woman. The result is the unconcealment of the truth of the shoes as they exist. The painting projects an open region in which we are able to transcend our world and enter into the world set up in the painting.

This transcendence frees us from forcing our directives onto the shoes because they carry no actual utilitarian value for us. We encounter the shoes without focusing on their external properties, how they affect us, or how they may be of use to us. The shoes are thereby free to direct us and we are free to bring ourselves into accord with their directives. Thus disposed, we are able to experience the event which occurs in the painting, what the shoes mean as they exist in the world of the peasant woman.

George Steiner explains that it is the actual presentation of the shoes by the painting that makes it possible for us to experience the innermost reality and meaning of the shoes. The insightful knowledge of the shoes granted by the painting is not attainable by 
scientific or logical investigation.49 Only art lets beings be. "Only in and through the painting does the pair of shoes achieve a total, autonomous being per se." The painting preserves and guards the existential inscape and living presence of the shoes even after they are no longer of scientific interest or practical use. The shoes are familiar to us, but through the work of art they are distanced from their facticity and drawn into the essential truth of their being.50

Thus, through the painting we are able to transcend our world and in so doing we are able to view the shoes in a fresh light. We no longer see them as equipment awaiting our immediate use. The painting moves us beyond the use and definition our needs and conveniences have imposed and enables us to encounter the shoes as independent, self-existent beings. The painting itself is a thing which establishes and secures the conditions necessary for the disclosure of truth. Through the painting the shoes are able to stand opposed as the things that they are. The painting detaches the shoes from ourselves. This distancing of the shoes helps to achieve our freedom to let them be the thing that they are by removing them from the context of our world. Since the painted shoes can be of no practical use to us, we cannot approach them as equipment awaiting our directives. We are, therefore, unable to force our directives upon them. Consequently, we are free to be guided by their directives. The meaning of the shoes is secured by the world which is set up in the painting. Through their meaning the shoes also disclose a truth about the peasant woman as she exists in her world.

49 Steiner, op. cit., p. 133.

50 Ibid., p. 134. 
However, Meyer Schapiro points out that the shoes in the painting are not the shoes of a peasant woman but are in fact Van Gogh's shoes, the shoes of a town and city man. He further suggests that it is impossible to say properly that the painting expresses the essence of the peasant woman's shoes and her relation to nature and work.51 Therefore, Heidegger's associations are not sustained by the painting itself but are grounded in Heidegger's subjective outlook.

Thus, Heidegger has projected images into the painting.52

Schapiro raises a significant point. Assuming he is correct, we must ask whether or not the individualized aspect of the shoes in the world of the peasant woman can be universalized through Heidegger's interpretation. In other words, we are inquiring as to whether or not the same truth of the shoes can emerge from their existing in a different world. If we interpret the world set up in the painting as a world of a town and city man, we can conclude that the primary meaning that the shoes holds for him is the same as that which they hold in the world of the peasant woman. Heidegger explains the truth disclosed in the painting as follows:

The peasant woman wears her shoes in the field. Only here are they what they are. They are all the more genuinely so, the less the peasant woman thinks about the shoes while she is at work, or looks at them at all, or is even aware of them. She stands and walks in them. This is how shoes actually serve. It is in this process of the use of equipment that we must actually encounter the character of equipment.(Origin, 162)

51 Meyer Schapiro, "The Still Life as a Personal Object - A Note on Heidegger and Van Gogh," in The Reach of Mind, ed. by M.L. Simmel (New York: Springer Publishing Company, 1968) p. 205.

52 Ibid., p. 206. 
The truth of the shoes rests in their usefulness. Heidegger explains that the peasant woman stands and walks in them and that is how they serve. The same is true of the town and city man, for they mean the same to his existence as they do for that of the peasant woman. The city man also stands and walks in his shoes; thus, they serve him in the same primary manner as they serve the peasant woman. All that Heidegger depicts in his imagery of the peasant woman's world is easily adapted to the world of the city man; yet, the meaning of the shoes remains the same. If we refer back to the conditions necessary for the disclosure of truth, we find that reflection is a necessary condition. Heidegger indicates the need to reflect upon the painting in the following passage:

As long as we only imagine a pair of shoes in general, or simply look at the empty, unused shoes as they merely stand there in the picture, we shall never discover what the equipmental being of the equipment in truth is. From Van Gogh's painting we cannot even tell where these shoes stand. ... And yet (Origin, 163)

Here Heidegger is acknowledging the need for reflection. Even he realizes that the shoes alone are not disclosing truth. The event of truth occurs because through the painting the openness of the open region is held open. We are thereby able to achieve attunement with the truth of the shoes because we are free to see them as something more than a piece of equipment ready for our using. Instead, we are able to reflect on what the shoes mean because there is no possibility of our using them; and their meaning is universal. Thus, we engage the truth of the piece of equipment and through that truth we also engage a truth about ourselves, for the shoes only have meaning because they are part of our world. 
R. Raj Sing helps to explain that the painting does not only reveal the earth and world of the peasant woman but also the earth and world in general. Thus, the distinctive role of the painting "lies in revealing the worldhood of the world and the earthiness of the earth, and not merely a specific world and a specific earth."53 It seems that we have to accept this universal aspect of earth and world, for there needs to be something common between audience and artwork in order for the audience to understand the revelation. In relation to Schapiro's charge, this means that the universal aspect of the shoes, what they are in relation to world, is the event of truth. Thus, we are lead to the same conclusion that the localized interpretation of the peasant woman's world assists in conveying the universal aspect.

The specifics of the localized interpretation do not seem essential to the event which occurs in the painting, the truth of a pair of shoes. The question is whether or not it is necessary for the work of art to disclose accurately the world in which the shoes belong, or whether it is enough that it discloses the truth of the shoes in their relation to us as equipment. Although the answer is uncertain, it seems at least possible that the accurate disclosure of a world is not essential to all works of art. For example, the Greek temple discloses the truth of the temple, and through its relationship with the Greeks, its meaning for them; it also discloses their historical epoch. The meaning of the temple depends on the world of the Greeks. The shoes, however, may maintain the same meaning for different worlds that utilize them as equipment. Although the shoes may reveal a

$53 \quad$ Sing, op. cit., p. 216. 
truth about an historical world, it is arguable that their truth as equipment is the same in different worlds that utilize them.

Schapiro continues to charge that, even if Heidegger's interpretation of the shoes was correct, it is a mistake to suppose that the truth revealed in the painting could not be attained from the actual shoes.54 He also charges that Heidegger is mistaken when he claims that the user of equipment does not reflect on it and therefore fails to encounter a truth about the world. Schapiro cites Van Gogh's painting of his own shoes as an example.55 Heidegger would agree with this example.

For Heidegger, art requires techne. Techne is not just bringing forth; it is also knowledge. This is the gift of the artist. The world of the artist is to listen to the telling of truth and to bring it to stand. The artist is able to experience truth without having to be transported from his world. Moreover, Heidegger admits that the user of the equipment, the peasant woman, does know something about the shoes. She knows of their reliability; and she knows of this without noticing or reflecting.(Origin, 163) Reflection, however, is needed for encountering meaning and all that it reveals. In fact, Heidegger says that the peasant woman's shoes are all the more genuinely the equipment that they are "the less the peasant woman thinks about the shoes while she is working, or looks at them at all, or is aware of them."(Origin, 162) Heidegger would disagree with regard to the observation of the thing. Mere observation keeps us

\footnotetext{
54 Schapiro, op. cit., p. 206.

55 Ibid., p. 207. Schapiro also offers Knut Hamsun's description of his own shoes in his novel Hunger to illustrate that the user does reflect on the thing. However, the user in this example is also the artist; therefore, the argument which applies to Van Gogh also applies here.
} 
too distant from the thing or fails to provoke us to transcend our world of existence. Art, however, avoids both of these hinderances to unconcealment and provokes us to reflect, something which is not usually enticed by the mere observation or use of the thing, mostly because we force our directives onto the thing during these encounters. It is possible for truth to be disclosed in the actual encounter of the shoes as long as the conditions necessary for the disclosure are met. 


\section{CONCLUSION}

For Heidegger, the disclosure of truth depends upon the conditions of the encounter. Approaching things as objects possessing certain traits, having particular affects on us, or performing specific functions for us inhibits our experiencing truth. Since things find meaning through our relationship with them, we must be able to encounter that relationship when we approach things. In order to accomplish this, we must be able to look onto that relationship. This requires distancing. We must distance ourselves from willing our directives onto things. By allowing the thing to direct us, we discover the meaning that the thing holds for us. This discovery discloses the truth of the thing, and by so doing, it also discloses a truth about ourselves.

Heidegger recognizes that our everyday approach toward things refuses to allow things to set the directives because our everyday approach is predetermined by our immediate needs. Truth is, therefore, not attainable through our ordinary encounters with things. Artworks, however, are things which are able to force directives onto us by removing us from our ordinary encounter with things. By establishing the conditions necessary for the disclosure of truth, we are able to experience truth through works of art. Our examination of Heidegger's thought has lead us to the conclusion that artworks are the only things that are able to disclose truth.

For Heidegger, an artwork captures the truth of things and makes that truth accessible to us. We see things in a different light 
when we view them through works of art. Art almost allows us to experience things for the first time; at least, works of art allow us to experience things in a new way. Art gives insight as to how things are. We discover the truth of ourselves, how we live and interact in relation to the things around us and in relation to each other. A work of art provides a window through which we can view our existence unhindered by preoccupations with the directives of will. Heidegger is reminiscent of the ancient world, a world which listened to hear the truth of beings and lived within their dictates. Art reminds us that we need to listen. It enables us to step back and look toward truth. 


\section{WORKS CITED}

Heidegger, Martin, "The Origin of the Work of Art," in Martin Heidegger Basic Writings, ed. by David Farrell Krell, Harper \& Row Publishers, New York, 1977, pp. 149-187.

Heidegger, Martin, "On the Essence of Truth," in Martin Heidegger Basic Writings, ed. by David Farrell Krell, Harper \& Row Publishers, New York, 1977, pp. 117-141.

Heidegger, Martin, "The Question Concerning Technology," in Martin Heidegger Basic Writings, ed. by David Farrell Krell, Harper \& Row Publishers, New York, 1977, pp. 287-317.

Arendt, Hannah, "Martin Heidegger at Eighty," in Heidegger and Modern Philosophy Critical Essays, ed. by Michael Murray, Yale University Press, New Haven, 1978, pp. 293-303.

Alderman, Harold, "Heidegger's Critique of Science and Technology," in Heidegger and Modern Philosophy Critical Essays, ed. by Michael Murray, Yale University Press, 1978,pp. 35-50

Ballard, Edward, "Heidegger's View and Evaluation of Nature and Natural Science," in Heidegger and the Path of Thinking ed. by John Sallis, Duquesne University Press, 1970, pp. 37-65.

Lingis, A.F., "On the Essence of Technique," in Heidegger and the Quest forTruth, ed. by Manfred S. Frings, Quadrangle Books, Chicago, 1968, pp. 126-138.

Steiner, George, Martin Heidegger, The Viking Press, New York, 1978.

Biemel, Walter, "Elucidations of Heidegger's Lecture the Origin of Art and the Destination of Thinking," in On Heidegger and Language, ed. by Joseph Kockelmans, Northwestern University Press, Evanston, 1972, pp. 370-382.

Taminiaux, Jacques, "The Origin of The Origin of the Work of Art," in Reading Heidegger Commemorations, ed. by John Sallis, Indiana University Press, Bloomington, 1993, pp. 392-404. 
Birault, Henri, "Thinking and Poetizing in Heidegger," in On Heidegger and Language, ed. by Joseph Kockelmans, Northwestern University Press, Evanston, 1973, pp. 147-168.

Singh, R. Raj, "Heidegger and the World in an Artwork," in The Journal of Aesthetics and Art Criticism, vol. 48 no. 3, Summer 1990, pp. 215- 222.

Smith, Joseph, "In-the-World and On-the-Earth: A Heideggerian Interpretation," in Heidegger and the Quest for Truth, ed. by Manfred S. Frings, Quadrangle Books, Chicago, 1968, pp. 184203.

Schumacher, Paul, "Art for Existence's Sake: A Heideggerian Revision," in Journal of Aesthetic Education, vol. 24 no. 2, Summer 1990, pp. 83-89.

Owens, Wayne, "Heidegger's Philosophy of Art," in British Journal of Aesthetics, vol. 29 no. 2, Spring 1989, pp. 128-139.

Schapiro, Meyer, "The Still Life as a Personal Object - A Note on Heidegger and Van Gogh," in The Reach of Mind, ed. by M.L. Simmel Springer Publishing Company, 1968, pp. 203-209. 


\section{BIBLIOGRAPHY}

Alderman, Harold, "Heidegger's Critique of Science and Technology," in Heidegger and Modern Philosophy Critical Essays, ed. by Michael Murray, Yale University Press, New Haven, 1978, pp. 35-50.

Arendt, Hannah, "Martin Heidegger at Eighty," in Heidegger and Modern Philosophy Critical Essays, ed. by Michael Murray, Yale University Press, New Haven, 1978, pp. 293-303.

Ballard, Edward G., "Heidegger's View and Evaluation of Nature and Natural Science," in Heidegger and the Path of Thinking, ed. by John Sallis, Duquesne University Press, Pittsburgh, 1970, pp. 37-65.

Biemel, Walter, "Elucidations of Heidegger's Lecture the Origin of Art and the Destination of Thinking," in Reading Heidegger Commemorations, ed. by John Sallis, Indiana University Press, Bloomington, 1993, pp. 370-382.

Biemel, Walter, "Poetry and Language in Heidegger," in On Heidegger and Language, ed. by Joseph Kockelmans, Northwestern University Press, Evanston, 1972, pp. 65-105.

Birault, Henri, "Thinking and Poetizing in Heidegger," in On Heidegger and Language, ed. by Joseph Kockelmans, Northwestern University Press, Evanston, 1972, pp. 147-168.

Bloom, S. and Hill, E., "Borrowed Shoes," in Artforum, vol. 26, April 1988, pp. 111-117.

Brogan, Walter, "The Battle between Art and Truth: A Reconsideration," in Philosophy Today, vol. 28, Winter 1984, pp. 349-357.

Goldman, Alan H., "Art Historical Value," in British Journal of Aesthetics, vol. 33 no. 1, January 1993, pp. 17-28.

Heidegger, Martin, "On the Essence of Truth," in Martin Heidegger Basic Writings, ed. by David Krell, Harper \& Row Publishers, 
1977, pp. 117-141.

Heidegger, Martin, "The Origin of the Work of Art," in Martin Heidegger Basic Writings, ed. by David Krell, Harper \& Row Publishers, 1977 pp. 149-187.

Heidegger, Martin, "The Question Concerning Technology," in Martin Heidegger Basic Writings, ed. by David Krell, Harper \& Row Publishers, 1977, pp. 287-317.

Hoeller, Keith, "Role of the Early Greeks in Heidegger's Turning," in Philosophy Today, vol. 28, Spring 1984, pp. 44-51.

Keyes, C.D., "Truth as Art: An Interpretation of Seit und Zeit (sec. 44) and Der Ursprung Des Kunstwerkes," in Heidegger and the Path of Thinking, ed. by John Sallis, Duquesne University Press, Pittsburgh, 1990, pp. 65-84.

Kockelmans, Joseph J., "Thanks-giving: The Completion of Thought," in Heidegger and the Quest for Truth, ed. by Manfred S. Frings, Quadrangle Books, Chicago, 1968, pp. 163-183.

Langan, Thomas, "Heidegger: The Problem of the Thing," in Heidegger and the Path of Thinking, ed. by John Sallis, Duquesne University Press, Pittsburgh, 1970, pp. 105-115.

Lingis, A.F., "On the Essence of Technique," in Heidegger and the Quest for Truth, ed. by Manfred S. Frings, Quadrangle Books, Chicago, 1968, pp. 126-138.

Marx, Werner, "The World in Another Beginning: Poetic Dwelling and the Role of the Poet," in On Heidegger and Language, ed. by Joseph Kockelmans, Northwestern University Press, Evanston, 1972, pp. 235-259.

Owens, Wayne D., "Heidegger's Philosophy of Art," in British Journal of Aesthetics, vol. 29 no. 2, Spring 1989, pp. 128-139.

Platt, Robert, "Aesthetic Crisis and Artwork," in The Journal of Aesthetics and Art Criticism, vol. 44, Summer 1986, pp. 339349 .

Sallis, John, "Towards the Movement of Reversal: Science, Technology, 
and the Language of Homecoming," in Heidegger and the Path of Thinking, ed. by John Sallis, Duquesne University Press, Pittsburgh, 1970, pp. 138-168.

Schapiro, Meyer, "The Still Life as a Personal Object - A Note on Heidegger and Van Gogh," in The Reach of Mind, ed. by M.L. Simmel, Springer Publishing Company, New York, 1968, pp. 203-209.

Schumacher, Paul, "Art for Existence Sake: A Heideggerian Revision," in Journal of Aesthetic Education, vol. 24 no. 2, Summer 1990, pp. 83-89.

Singh, R. Raj, "Heidegger and the World in an Artwork," in The Journal of Aesthetic and Art Criticism, vol. 48 no. 3, Summer 1990, pp. 215-222.

Smith, F. Joseph, "In-the-World and On-the-Earth: A Heideggerian Interpretation," in Heidegger and the Quest for Truth, ed. by Manfred S. Frings, Quadrangle Books, Chicago, 1968, pp. 184203.

Steiner, George, Martin Heidegger, The Viking Press, New York, 1978.

Taminiaux, Jacques, "The Origin of 'The Origin of the Work of Art'," in Reading Heidegger Commemorations, ed. by John Sallis, Indiana University Press, Bloomington, 1993, pp. 392-404. 